Article

\title{
Haplotype in SERPINA1 (AAT) Is Associated with Reduced Risk for COPD in a Mexican Mestizo Population
}

\author{
Marco Antonio Ponce-Gallegos ${ }^{1}$ (D), Gloria Pérez-Rubio ${ }^{1}$, Adriana García-Carmona ${ }^{1}$, \\ Jesús García-Gómez ${ }^{1}$, Rafael Hernández-Zenteno ${ }^{2}$, Alejandra Ramírez-Venegas ${ }^{2, *}$ and \\ Ramcés Falfán-Valencia ${ }^{1, *(D)}$ \\ 1 HLA Laboratory, Instituto Nacional de Enfermedades Respiratorias Ismael Cosio Villegas, \\ Mexico City 14080, Mexico; marcoapg@iner.gob.mx (M.A.P.-G.); glofos@yahoo.com.mx (G.P.-R.); \\ adri_garcia_168@hotmail.com (A.G.-C.); jesus.garcia3232@alumnos.udg.mx (J.G.-G.) \\ 2 Tobacco Smoking and COPD Research Department, Instituto Nacional de Enfermedades Respiratorias \\ Ismael Cosio Villegas, Mexico City 14080, Mexico; rafherzen@yahoo.com.mx \\ * Correspondence: aleravas@hotmail.com (A.R.-V.); rfalfanv@iner.gob.mx (R.F.-V.); \\ Tel.: +52-55-5487-1700 (ext. 5305) (A.R.-V.); +52-55-5487-1700 (ext. 5152) (R.F.-V.)
}

Received: 4 November 2019; Accepted: 19 December 2019; Published: 27 December 2019

check for updates

\begin{abstract}
Protease inhibitor S (PiS) and protease inhibitor Z (PiZ) variants in the SERPINA1 gene are the main genetics factors associated with COPD; however, investigations about other polymorphisms are scanty. The aim of this study was to evaluate two missense single nucleotide polymorphisms (SNPs) (rs709932 and rs1303) in the SERPINA1 gene in Mexican mestizo patients with chronic obstructive pulmonary disease (COPD) related to tobacco smoking and biomass-burning exposure. 1700 subjects were genotyped and divided into four groups: COPD related to tobacco smoking (COPD-S, $n=297$ ), COPD related to biomass-burning exposure (COPD-BB, $n=178$ ), smokers without COPD (SWOC, $n=674$ ), and biomass-burning exposed subjects (BBES, $n=551$ ) by real-time PCR. Moreover, the patients' groups were divided according to their exacerbations' frequency. We carried out a haplotype analysis. We did not find differences in allele and genotype frequencies between groups in unadjusted and adjusted analyses, neither with these SNPs and lung function decline. Exacerbations' frequency is not associated with these SNPs. However, we found a haplotype with major alleles (CT) associated with reduced risk for COPD $(p<0.05)$. Our analysis reveals that SNPs different from PiS and PiZ (rs709932 and rs1303) in the SERPINA1 gene are not associated with COPD and lung function decline in a Mexican mestizo population. However, a haplotype shaped by both major alleles (CT haplotype) is associated with reduced risk for COPD.
\end{abstract}

Keywords: COPD; tobacco smoking; biomass burning; SNPs; SERPINA1; PiS; PiZ

\section{Introduction}

In accordance with the Global Initiative for Chronic Obstructive Lung Disease (GOLD), Chronic Obstructive Pulmonary Disease (COPD) is a common, preventable, and treatable disease characterized by persistent respiratory symptoms and airflow limitation. These conditions are mainly caused by significant exposure to noxious particles or gases, being the most important tobacco smoking and biomass-burning exposure [1].

Nowadays, COPD is considered the fourth leading cause of death worldwide [1]. The Global Burden of Disease Study from 2002 to 2030 reports a prevalence of 251 million cases of COPD globally in 2016. Prevalence in Mexico was estimated at 7.8\% by PLATINO study in 2005 [2,3]. 
Risk factors to develop COPD have been widely described. Alpha-1 antitrypsin deficiency (AATd) is the most important genetic risk factor associated with COPD [4]. AAT is a $52 \mathrm{kDa}$ sialoglycoprotein encoded by the SERPINA1 gene whose one of principal function is to protect the lower respiratory tract of lungs from proteolytic degradation by neutrophil elastase [5]. The common genotype for SERPINA1 (AAT) is described as PiMM and by protein serum levels between 150 and $350 \mathrm{mg} / 100 \mathrm{~mL}$. PiS and $\mathrm{PiZ}$ are the genetic variants characteristic of AATd patients. It has been previously described that individuals carrying on SS, SZ, and ZZ genotypes express serum protein concentrations of $85 \%, 25 \%$, and $15 \%$, respectively [6].

Despite PiS and PiZ variants represent approximately $95 \%$ of the AATd cases, there are other rare variants codified in the SERPINA1 gene, such as Siiyama, Mmalton, Mprocida, Mheerlen, Mmineral springs, Mnichinan, Pduarte, Wbethesda Zaugsberg, and Zbristol that could confer risk to COPD, but there are not enough studies to support it [5].

Most of the studies of AATd have been realized in subjects with COPD related to tobacco smoking. There are no studies in patients with COPD related to biomass-burning exposure. In Mexican mestizo population, Pérez-Rubio et al. [7] studied two single nucleotide polymorphisms (SNPs) in SERPINA1 (rs28929474 [PiZ] and rs17580 [PiS]), finding that homozygous and heterozygous (to minor allele in each case) are in a very low frequency in Mexican population. However, those subjects in the heterozygous state had poorer lung function measurements. On the other hand, Fernández-Acquier and colleagues [8] identified genetic variants different from PiS and PiZ and low serum AAT levels.

Our aim was to study two SNPs in SERPINA1 (rs709932 and rs1303) different from PiS and PiZ in a Mexican mestizo population with COPD related to tobacco smoking and biomass-burning exposure.

\section{Results}

One thousand and seven hundred subjects were included in two cases groups and two control groups; 297 patients with COPD related to tobacco smoking (COPD-S), 178 patients with COPD related to biomass burning smoke exposure (COPD-BB), 674 smokers without COPD (SWOC), and 551 biomass-burning exposed subjects without COPD (BBES).

\subsection{Demographic Variables}

We found statistical differences in age (cases are older than controls in both comparisons), sex (in the COPD-S group subjects are predominantly men; while in COPD-BB women predominate), body mass index (BMI, COPD subjects in both comparisons have a lower BMI than their respective controls), biomass exposure index (BEI), smoking status, and pulmonary function $(p<0.05)$. Demographic and clinical data are shown in Table 1.

In addition, a comparison between COPD-S vs. COPD-BB was performed. We found that COPD-BB patients are older than COPD-S and predominantly women $(p<0.05)$. Moreover, we found that patients in COPD-S are in more advanced GOLD stages and have worse pulmonary function than the COPD-BB group $(p<0.05)$. These results are shown in Supplementary Table S1.

\subsection{Demographic Variables in COPD Related to Tobacco Smoking and Biomass Burning and Exacerbations Frequency}

We compared frequent-exacerbators (FE-S and FE-BB) against non-exacerbators (NEX-S and NEX-BB) within the COPD-S and COPD-BB groups and results are shown in Table 2. Age, sex, and smoking status did not show significant differences between FE-S and NEX-S $(p>0.05)$. However, comparing FE-BB vs. NEX-BB we found significant differences in age and BEI $(p<0.05)$. Interestingly, GOLD III and IV stages (G2) were more prevalent in the FE-S group, while GOLD I and II (G1) were more frequent in the NEX-S group. However, there were no significant differences between groups $(p>0.05)$. There were no significant differences when comparing G1 and G2 from FE-BB and NEX-BB groups, as well as there were no differences in lung function. 
Table 1. Demographic variables and pulmonary function data from the four groups.

\begin{tabular}{|c|c|c|c|c|c|c|}
\hline Variable & $\begin{array}{l}\text { COPD-S } \\
(n=297)\end{array}$ & $\begin{array}{c}\text { SWOC } \\
(n=674)\end{array}$ & $p$ & $\begin{array}{l}\text { COPD-BB } \\
(n=178)\end{array}$ & $\begin{array}{c}\text { BBES } \\
(n=551)\end{array}$ & $p$ \\
\hline Age, years & $67(50-80)$ & $55(35-90)$ & $<0.0001$ & $74(51-86)$ & $59(34-90)$ & $<0.0001$ \\
\hline Male, \% & 76.35 & 44 & & 8 & 0.5 & \\
\hline BMI & $24.5(13.5-36.1)$ & $27.5(13.7-47.0)$ & $<0.0001$ & $24.5(18.7-32.7)$ & $28.2(15.7-44.9)$ & 0.008 \\
\hline Biomass exposure status & NA & NA & & & & \\
\hline Years exposed & & & & $50(10-80)$ & $40(1-87)$ & $<0.0001$ \\
\hline Hours per day & & & & $7(2-24)$ & $5(1-24)$ & $<0.0001$ \\
\hline Biomass exposure index & & & & $360(140-828)$ & $200(2-1050)$ & $<0.0001$ \\
\hline Smoking status & & & & NA & NA & \\
\hline Years of smoking & $42(10-68)$ & $34(4-65)$ & $<0.0001$ & & & \\
\hline Cigarettes per day & $20(5-80)$ & $14(1-100)$ & $<0.0001$ & & & \\
\hline Tobacco index & $40(10-232)$ & $20(1-175)$ & $<0.0001$ & & & \\
\hline $\begin{array}{c}\text { Current smokers, \% } \\
\text { GOLD }\end{array}$ & 69.59 & 20.3 & $<0.0001$ & & & \\
\hline GOLD I, $\%$ & 14.73 & & & 27.21 & & \\
\hline GOLD II, \% & 44.52 & & & 54.41 & & \\
\hline GOLD III, \% & 29.11 & & & 15.44 & & \\
\hline GOLD IV, \% & 11.64 & & & 2.94 & & \\
\hline \multicolumn{7}{|l|}{ Lung function } \\
\hline FVC (\%) post & $78(24-155)$ & $95(18-139)$ & $<0.0001$ & $79(43-144)$ & $100(53-193)$ & $<0.0001$ \\
\hline FEV1 (\%) post & $42(12-88)$ & $98(23-142)$ & $<0.0001$ & $48(18-94)$ & $105(53-187)$ & $<0.0001$ \\
\hline FEV1/FVC (\%) post & $52(26.1-69.4)$ & $103.7(70-132.8)$ & $<0.0001$ & $60.9(36.7-68.4)$ & $105(70-142.4)$ & $<0.0001$ \\
\hline
\end{tabular}

Table 2. Demographic variables among chronic obstructive pulmonary disease (COPD) patients FE-S, NEX-S, FE-BB, and NEX-BB.

\begin{tabular}{|c|c|c|c|c|c|c|}
\hline Variable & $\begin{array}{c}\text { FE-S } \\
(n=32)\end{array}$ & $\begin{array}{l}\text { NEX-S } \\
(n=87)\end{array}$ & $p$ & $\begin{array}{c}\text { FE-BB } \\
(n=38)\end{array}$ & $\begin{array}{l}\text { NEX-BB } \\
(n=47)\end{array}$ & $p$ \\
\hline Age, years & $67(52-77)$ & $65(47-80)$ & 0.855 & $68(61-86)$ & $75(51-86)$ & 0.014 \\
\hline Male, \% & 78.12 & 75.86 & 0.796 & 10.53 & 6.38 & 0.489 \\
\hline Body mass index & $24.6(15.2-35.9)$ & $24.8(16.9-36.1)$ & 0.88 & $23.8(20-30.3)$ & $24.9(18.7-31.1)$ & 0.824 \\
\hline Biomass burnings status & NA & NA & & & & \\
\hline Years exposed & & & & $45(10-75)$ & $50(14-80)$ & 0.406 \\
\hline Hours per day & & & & $6(2-18)$ & $8(2-24)$ & 0.820 \\
\hline Biomass Exposure Index & & & & $300(140-800)$ & $375(144-828)$ & 0.025 \\
\hline Smoking status & & & & NA & NA & \\
\hline Years of smoking & $40(30-65)$ & $40(15-64)$ & 0.834 & & & \\
\hline Cigarettes per day & $20(10-40)$ & $20(5-40)$ & 0.859 & & & \\
\hline Packs-year history & $39.5(16-100)$ & $40(10-106)$ & 0.7 & & & \\
\hline \multicolumn{7}{|l|}{ GOLD } \\
\hline G1 (I-II), \% & 43.75 & 63.22 & \multirow[b]{2}{*}{0.056} & 81.48 & 79.41 & \multirow[b]{2}{*}{0.839} \\
\hline G2 (III-IV), \% & 56.25 & 36.78 & & 18.52 & 20.59 & \\
\hline \multicolumn{7}{|l|}{ Lung function } \\
\hline FVC (\%) post & $76.5(32-121)$ & $84(37-155)$ & 0.172 & $87(69-135)$ & $76(49-127)$ & 0.469 \\
\hline FEV1 (\%) post & $35.5(14-66)$ & $44(18-83)$ & 0.164 & $51(34-60)$ & $47(18-81)$ & 0.891 \\
\hline FEV1/FVC (\%) post & $48.4(29.1-65.8)$ & $52.4(26.1-69.4)$ & 0.45 & $55.6(37-69)$ & $63(36.7-69.4)$ & 0.44 \\
\hline
\end{tabular}

FE-S = Patients with COPD related to tobacco smoking frequent exacerbators, NEX-S = Patients with COPD related to tobacco smoking non-exacerbators, FE-BB = Patients with COPD related to biomass burning frequent exacerbators, NEX-BB = Patients with COPD related to biomass burning non-exacerbators. G1 = GOLD I and GOLD II stages, G2 $=$ GOLD III and GOLD IV stages. NA = Not apply. All values are shown as median. Measures of lung function are post-bronchodilator use. $p$-value $<0.05$ was significative. We used the median test and Fisher exact test. Values are expressed as minimum and maximum.

Furthermore, we performed a comparison between FE-S vs. NEX-BB, finding that FE-S are predominantly men, are in more advanced GOLD stages, and have worse pulmonary function than FE-BB. The results are shown in Supplementary Table S2. In addition, results of logistic regression analysis by co-variables in the COPD-S and COPD-BB groups are shown in the Supplementary Tables S3 and S4, respectively.

\subsection{Allele and Genotype Association}

Two SNPs in SERPINA1 (rs709932 and rs1303) were evaluated in this study. We did not find any association with alleles and genotypes, as well as neither with dominant nor recessive models $(p>0.05)$. Table 3 shows the allele and genotype frequencies for both comparisons. Interestingly, the minor allele frequency (MAF) of rs709932 among smokers (COPD-S and SWOC) is twice higher than 
reported by Ensembl for Mexican from Los Angeles, in contrast with biomass-exposed groups, which is very similar. MAF of rs1303 is a little higher in four groups than reported by Ensembl.

Table 3. Allele and genotype frequencies of SERPINA1 single nucleotide polymorphisms (SNPs) evaluated.

\begin{tabular}{|c|c|c|c|c|c|c|c|c|}
\hline Genotype/Allele & \multicolumn{2}{|c|}{ COPD-S } & \multicolumn{2}{|c|}{ SWOC } & \multicolumn{2}{|c|}{ COPD-BB } & \multicolumn{2}{|c|}{ BBES } \\
\hline $\mathrm{CC}$ & 224 & 75.42 & 537 & 79.67 & 156 & 87.64 & 471 & 85.48 \\
\hline $\mathrm{CT}$ & 69 & 23.23 & 124 & 18.40 & 22 & 12.36 & 74 & 13.43 \\
\hline $\mathrm{T}$ & 77 & 12.96 & 150 & 11.13 & 22 & 6.18 & 86 & 7.80 \\
\hline CC & 224 & 75.42 & 537 & 79.79 & 156 & 87.64 & 471 & 85.48 \\
\hline $\mathrm{CT}+\mathrm{TT}$ & 73 & 24.58 & 137 & 20.36 & 22 & 12.36 & 80 & 14.68 \\
\hline $\mathrm{CC}+\mathrm{CT}$ & 293 & 98.65 & 661 & 98.07 & 178 & 100 & 545 & 98.91 \\
\hline TT & 4 & 1.35 & 13 & 1.93 & 0 & 0 & 6 & 1.09 \\
\hline GT & 130 & 43.77 & 271 & 40.21 & 73 & 41.01 & 250 & 45.37 \\
\hline GG & 36 & 12.12 & 65 & 9.64 & 25 & 14 & 92 & 16.70 \\
\hline $\mathrm{T}$ & 392 & 65.99 & 947 & 70.25 & 233 & 65.45 & 668 & 60.62 \\
\hline G & 202 & 34.01 & 401 & 29.75 & 123 & 34.55 & 434 & 39.38 \\
\hline $\mathrm{TT}$ & 131 & 44.11 & 338 & 50.15 & 80 & 44.94 & 209 & 37.93 \\
\hline $\mathrm{GT}+\mathrm{GG}$ & 166 & 55.89 & 336 & 49.85 & 98 & 64.05 & 342 & 74.51 \\
\hline $\mathrm{TT}+\mathrm{GT}$ & 261 & 87.88 & 609 & 91.17 & 153 & 85.96 & 459 & 83.30 \\
\hline GG & 36 & 12.59 & 65 & 9.73 & 25 & 14.04 & 92 & 16.70 \\
\hline
\end{tabular}

COPD-S = Patients with COPD related to tobacco smoking, SWOC $=$ Smokers without COPD, COPD-BB $=$ Patients with COPD related to biomass-burning exposure, BBES = Biomass-burning exposed subjects. GF $=$ Genotype frequency, $\mathrm{AF}=$ Allele frequency.

Due to the differences found in the clinical and demographic variables, we decided to make an analysis adjusted by covariables (age and tobacco index for smokers' groups and age and biomass exposure index for those groups exposed to biomass burning) performing a logistic regression test.

Adjusting only by age and tobacco index in COPD-S vs. SWOC, we found statistically significant results for rs1303 $\left(p=5.82 \times 10^{-27}, \mathrm{OR}=1.12, \mathrm{CI} 95 \% 1.10-1.15 ; p=7.44 \times 10^{-15}, \mathrm{OR}=1.03, \mathrm{CI} 95 \%\right.$ 1.03-1.04, respectively) and rs709932 ( $p=4.16 \times 10^{-7}, \mathrm{OR}=1.12, \mathrm{CI} 95 \% 1.10-1.15 ; p=1.09 \times 10^{-14}$, $\mathrm{OR}=1.03, \mathrm{CI} 95 \%$ 1.03-1.04, respectively). However, in the additive model, these associations are not maintained in both SNPs $(p \geq 0.05)$. This effect is the same for COPD-BB vs. BBES comparison adjusting by age and BEI, with significant differences with covariables alone in $\operatorname{rs} 1303\left(p=1.25 \times 10^{-13}\right.$, $\mathrm{OR}=1.08, \mathrm{CI} 95 \% 1.06-1.10 ; p=0.0003, \mathrm{OR}=1.002, \mathrm{CI} 95 \% 1.001-1.003$, respectively) and rs709932 $\left(p=2.24 \times 10^{-13}, \mathrm{OR}=1.08 \mathrm{CI} 95 \% 1.06-1.10 ; p=0.0004, \mathrm{OR}=1.002, \mathrm{CI} 95 \% 1.001-1.003\right.$, respectively $)$ and in additive model, these associations are not maintained in both SNPs $(p \geq 0.05)$. These results are shown in Supplementary material (Tables S1 and S2).

\subsection{Allele and Genotype Association with Exacerbations in COPD Related to Tobacco Smoking and Biomass-Burning Exposure Subjects}

Another analysis that was carried out was a comparison between FE-S vs. NEX-S and FE-BB vs. NEX-BB. Allele and genotype frequencies did no show statistically significant differences between groups and neither did dominant and recessive models $(p>0.05)$. The results are shown in Table 4. 
Table 4. Analysis of the association of alleles and genotypes in codominant, dominant, and recessive models between Frequent exacerbators and Non-exacerbators.

\begin{tabular}{|c|c|c|c|c|c|c|c|c|c|c|c|c|c|c|c|}
\hline \multirow{2}{*}{ SNP/Model } & \multirow{2}{*}{ Genotype/Allele } & \multicolumn{2}{|c|}{ FE-S } & \multicolumn{2}{|c|}{ NEX-S } & \multirow{2}{*}{$p$-Value } & \multirow{2}{*}{ OR } & \multirow{2}{*}{$95 \% \mathrm{CI}$} & \multicolumn{2}{|c|}{ FE-BB } & \multicolumn{2}{|c|}{ NEX-BBES } & \multirow{2}{*}{$p$-Value } & \multirow{2}{*}{ OR } & \multirow{2}{*}{$95 \% \mathrm{CI}$} \\
\hline & & $n=32$ & $\begin{array}{c}\text { GF/AF } \\
(\%)\end{array}$ & $n=87$ & $\begin{array}{c}\text { GF/AF } \\
(\%)\end{array}$ & & & & $n=38$ & $\begin{array}{c}\text { GF/AF } \\
(\%)\end{array}$ & $n=47$ & $\begin{array}{c}\text { GF/AF } \\
(\%)\end{array}$ & & & \\
\hline \multicolumn{16}{|c|}{ rs709932 } \\
\hline \multirow{3}{*}{ Codominant } & $\mathrm{CC}$ & 25 & 78.13 & 63 & 72.41 & \multirow{3}{*}{0.529} & 1.36 & $0.52-3.55$ & 34 & 89.47 & 40 & 85.11 & \multirow{3}{*}{0.55} & 1.49 & $0.40-5.52$ \\
\hline & $\mathrm{CT}$ & 7 & 21.88 & 24 & 27.59 & & 0.74 & $0.04-1.92$ & 4 & 10.53 & 7 & 14.89 & & 0.67 & $0.18-2.49$ \\
\hline & $\mathrm{TT}$ & 0 & 0 & 0 & 0 & & & & 0 & 0 & 0 & 0 & & & \\
\hline \multirow{2}{*}{ Alleles } & $\mathrm{C}$ & 57 & 89.06 & 150 & 86.21 & \multirow{2}{*}{0.561} & 1.30 & $0.53-3.10$ & 72 & 94.74 & 87 & 92.55 & \multirow{2}{*}{0.57} & 1.45 & $0.41-5.14$ \\
\hline & $\mathrm{T}$ & 7 & 10.94 & 24 & 13.79 & & 0.77 & $0.31-1.88$ & 4 & 5.26 & 7 & 7.45 & & 0.69 & $0.19-2.45$ \\
\hline \multirow{2}{*}{ Dominant } & CC & 25 & 78.13 & 63 & 72.41 & \multirow{2}{*}{0.529} & 1.36 & $0.52-3.56$ & 34 & 89.47 & 40 & 85.11 & \multirow{2}{*}{0.55} & 1.49 & $0.40-5.52$ \\
\hline & CT-TT & 7 & 21.88 & 24 & 27.59 & & 0.74 & $0.04-1.92$ & 4 & 10.53 & 7 & 14.89 & & 0.67 & $0.18-2.49$ \\
\hline \multirow{2}{*}{ Recessive } & CC-CT & 32 & 100 & 87 & 100 & & & & 38 & 100 & 47 & 100 & & & \\
\hline & TT & 0 & 0 & 0 & 0 & & & & 0 & 0 & 0 & 0 & & & \\
\hline \multicolumn{16}{|c|}{ rs1303 } \\
\hline \multirow{3}{*}{ Codominant } & $\mathrm{TT}$ & 14 & 43.75 & 39 & 44.83 & 1 & 1 & & 17 & 44.74 & 23 & 48.94 & 1 & & \\
\hline & GT & 16 & 50 & 38 & 43.68 & \multirow{2}{*}{0.656} & 1.17 & $0.50-2.73$ & 13 & 34.21 & 15 & 31.91 & \multirow{2}{*}{0.928} & 1.17 & $0.44-3.10$ \\
\hline & GG & 2 & 6.25 & 10 & 11.49 & & 0.56 & $0.11-2.86$ & 8 & 21.05 & 9 & 19.15 & & 1.20 & $0.38-3.76$ \\
\hline \multirow{2}{*}{ Alleles } & $\mathrm{T}$ & 44 & 68.75 & 116 & 66.67 & \multirow{2}{*}{0.761} & 1.1 & $0.59-2.04$ & 47 & 61.84 & 61 & 64.89 & \multirow{2}{*}{0.681} & 0.88 & \\
\hline & G & 20 & 31.25 & 58 & 33.33 & & 0.91 & $0.49-1.68$ & 29 & 38.16 & 33 & 35.11 & & 1.14 & $0.61-2.14$ \\
\hline Dominant & $\mathrm{TT}$ & 14 & 43.75 & 39 & 44.83 & 0.916 & 0.96 & $0.42-2.17$ & 17 & 44.74 & 23 & 48.94 & 0.699 & 0.84 & $0.36-1.99$ \\
\hline & GT-GG & 18 & 56.25 & 48 & 55.17 & & 1.04 & $0.46-2.36$ & 21 & 55.26 & 24 & 51.06 & & 1.18 & $0.50-2.79$ \\
\hline Recessive & TT-GT & 30 & 93.75 & 77 & 88.51 & 0.399 & 1.95 & $0.40-9.42$ & 30 & 78.95 & 38 & 80.85 & 0.827 & 0.89 & $0.31-2.58$ \\
\hline & GG & 2 & 6.25 & 10 & 11.49 & & 0.51 & $0.11-2.48$ & 8 & 21.05 & 9 & 19.15 & & 1.13 & $0.39-3.27$ \\
\hline
\end{tabular}

FE-S = Patients with COPD related to tobacco smoking frequent exacerbators, NEX-S = Patients with COPD related to smoking non-exacerbators. FE-BB $=$ Patients with COPD related to

biomass burning frequent exacerbators. NEX-BB: Patients with COPD related to biomass burning non-exacerbators. GF = Genotype frequency, $\mathrm{AF}=\mathrm{Allele}$ frequency. 


\subsection{SNPs Haplotypes in SERPINA1}

The haplotype analysis was conducted to determine its association with COPD susceptibility. The analysis included the two SNPs in the SERPINA1 gene, comparing COPD-S vs. SWOC and COPD-BB vs. BBES. Polymorphisms evaluated met Hardy-Weinberg equilibrium $(p>0.05)$. Haplotypes are shown in Figure 1. Figure 1A shows the haplotype in the comparison of COPD-S vs. SWOC. This haplotype is not in high linkage disequilibrium $\left(\mathrm{D}^{\prime}=89 ; \mathrm{r}^{2}=20\right)$. However, $\mathrm{CT}$ haplotype is associated with reduced risk for COPD $(\mathrm{OR}=0.81, p=0.048$, CI 95\% 0.66-0.99). Haplotype generated in COPD-BB vs. BBES comparison is shown in Figure 1B. This haplotype neither is in high linkage disequilibrium $\left(D^{\prime}=85 ; r^{2}=9\right)$. None of the haplotypes were associated.

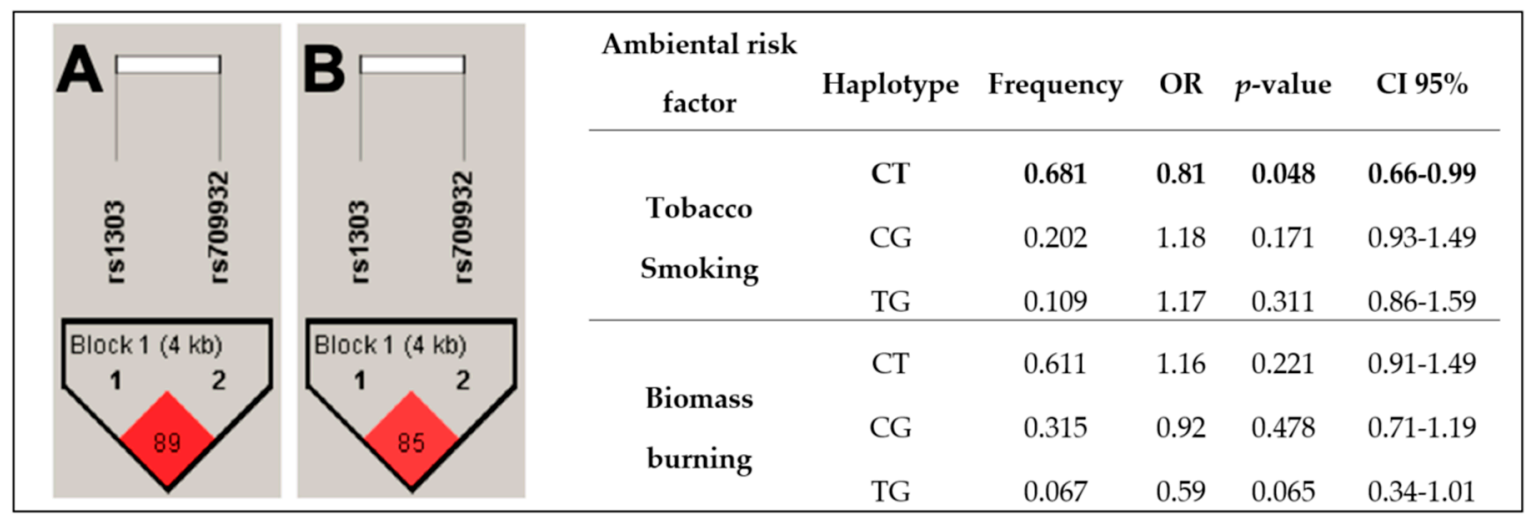

Figure 1. Haplotype analysis: Two SNPs were evaluated in both comparisons; among tobacco-smoking groups, the CT haplotype was identified associated with reduced risk. Panel A = COPD-S vs. SWOC; Panel B $=$ COPD-BB vs. BBES. $p$-value $<0.05$ was considered significative.

\subsection{SERPINA1 Variants and Lung Function}

We did not find any association with decreased lung function in COPD-S and COPD-BB groups and genotypes for both SNPs. Results are shown in Supplementary material (Figures S1-S4).

\section{Discussion}

In our study, we tried to identify two SNPs in the SERPINA1 gene that could confer risk for developing COPD related to tobacco smoking and biomass-burning, as well as their association with frequent exacerbator phenotype and lung function. It has been widely described that AATd is the most important genetic risk factor to develop COPD. Reduced circulating levels of alpha- 1 antitrypsin leads to increased neutrophil elastase activity in the lungs, which results in lung remodeling due to protease-antiprotease imbalance [9].

Regarding demographic variables, in the comparison between COPD-S vs. SWOC, the prevalence of the disease is higher in men, while in COPD-BB vs. BBES disease is more prevalent in women, similar to previous reports [3,10]; previously we have described [11] these differences in sex distribution between groups, which are due to historical and sociocultural backgrounds. Since it is common in rural regions to find a greater number of people exposed to BBS, and at the same time, this exposed group are women in charge of household chores (mainly cooking), activity in which usually use some kind of biomass to start and maintain the combustion to heat meals. For this reason, the biomass burning-smoke group had a predominance of females.

Moreover, in both comparisons, cases are older and have higher values for tobacco-smoking variables and biomass-burning and poor lung function than their respective controls, which is expected because it is the most important parameter to differentiate between cases and controls.

Arkhipov et al. [12] described that GOLD II and III stages are the most prevalent, coinciding with our findings in both cases groups. We did not find differences in age in FE-S vs. NEX-S and FE-BB vs. NEX-BB comparisons. Interestingly, those patients in G2 tend to present more exacerbations per 
year in the FE-S group. In FE-BB vs. NEX-BB, there were no significant differences. These findings are consistent with those reported by large prospective cohorts such as SUPPORT trial, SPIROMICS, and ECLIPSE, where they described that those patients in GOLD III and IV have more exacerbations per year. However, they also comment that COPD is very variable and that in a follow-up of three years only a low percentage remains as FE, and those who are classified as NEX can also change to FE [12-14] due to the multiple factors that participate in its appearances, such as age, disease severity, poor lung function, use of inhaled corticosteroids, and at least one exacerbation in last year [15].

In 1999, Hill et al. [16] described that patients with AATd had lower AAT sputum levels and secretory leukoprotease inhibitor (SLPI), as well as higher elastase activity at the start of exacerbation, compared with COPD patients without deficiency, suggesting that patients with AATd have a higher risk for severe exacerbations. The importance of exacerbations in COPD patients reside in the fact that they generate a decrease in quality of life, promote worsening and progression of the disease, and are the main cause of death in patients with COPD.

In our analysis of allele and genotype association with COPD, rs709932 and rs1303 did not show statistically significant results in any of both comparisons. There are few reports about these SNPs and their association with COPD. One of them, in accordance with our results, Fujimoto et al. [17] evaluated 12 SNPs in SERPINA1 (rs8004738, rs17751769, rs709932, rs11832, rs1303, rs28929474, and rs17580), SERPINA3 (rs4934, rs17473, and rs1800463), and SERPINE2 (rs840088 and rs975278) and did not find association with rs709932 and rs1303, only did with SERPINE2 SNPs.

Other studies have evaluated other genetic variants in SERPINA1. For example, Quint and colleagues [18] reported that SERPINA1 11478G $\rightarrow$ A variant is not associated with a major risk for developing COPD in a UK population. On the other hand, Deng et al. [19] described an association with a higher risk for COPD with rs8004738 (G/A) in a Chinese population. Our research group previously reported that PiZ (rs28929474, G/A) and PiS (rs17580, A/T) were not associated with COPD in a Mexican mestizo population. However, there was an association with rs17580 and decreased FEV1/FVC ratio. Interestingly, in a subsequent analysis of increasing sample size, it was described that heterozygous genotype (AT) in rs17580 is associated with a higher risk for COPD, being more important in COPD related to biomass-burning smoke $(\mathrm{OR}=11.5)$ [20]. There are no previous studies that evaluate SERPINA1 SNPs difference from PiS and PiZ and their association with COPD related to biomass-burning smoke.

Previous studies have tried to find an association with SNPs and exacerbations frequency, due to the clinical importance in patients with COPD, with positive results in chemokine ligand 1 [21] and surfactant protein B and D [22]. Conversely, Dicker et al. [23] and Platé and colleagues [24] described a reduced risk for exacerbations with SNPs in $M B L$ and PAR1, respectively. There is only one previous study that evaluates SNPs in SERPINA1 and its association with exacerbations frequency; similar to our results, authors did not find differences in genotypes between frequent and infrequent exacerbators and neither with AAT serum levels [18]. In addition, Ingebrigtsen et al. [25] found that having at least one plasma $\alpha 1$-antitrypsin-lowering Z-allele (MZ, SZ, or ZZ) was associated with increased risk for COPD exacerbations. In contrast, the $S$ allele was not associated with exacerbations.

Interestingly, we found a haplotype associated with reduced risk for COPD related to tobacco smoking. To our knowledge, it has been never reported before. However, Chappel and colleagues [26] evaluated 10 SNPs in SERPINA1 (including rs709932) and five in SERPINA3 and they found six haplotypes in SERPINA1 that confer risk of disease by six- to 50-fold. On the other hand, this is the first study that assesses rs709932 and rs1303 in COPD related to biomass-burning exposure, so we do not have a benchmark in this case.

Despite $\mathrm{S}$ and $\mathrm{Z}$ alleles have been described as the most common risk variants for COPD, some other studies have found risk variants different from PiS and PiZ. For example, Echazarreta et al. [27] measured the plasmatic levels of AAT in Argentinian subjects with chronic pulmonary diseases and pneumothorax and found AATd in almost a quarter of their study group. After genotyping, 7 patients with ZZ, 3 with SZ, 2 with SS, 8 with MZ, and 33 with MS genotype were found. However, most of the 
subjects evaluated with AATd showed a different genotype than S or Z. In addition, Kevorkof et al. [28] and Sorroche and colleagues [29] in their respective cohorts also found a high number of patients with genotype different than $\mathrm{S}$ or $\mathrm{Z}$ with AATd. These studies show the importance of evaluating different variants that could be involved in the development of COPD.

Previous studies have identified rs709932 and rs1303 as PiM2 and PiM3 variants, respectively [30-32]. In that context, despite these alleles are considered as "normal", in a Tunisian population, PiM2 allele has been identified as a risk factor for COPD with higher frequency in COPD patients than controls [33]. Moreover, Gupta et al. [34] in an Indian population described that PiM3 was more frequent in COPD patients than healthy controls. Thus far, how this normal allele variants, which expressing normal levels of AAT, participate in the pathogenesis of COPD is unclear [30,34].

There are several studies that have tried to identify SNPs associated with lung function decline with controversial results. Genetic variants in NLRP, MMP3, IL8, TIMP1, and EDN1 have been previously associated with the worsening of COPD and FEV1 decline in different populations [35-39]. In addition, Gian-Andri et al. [40] described that in the SAPALDIA cohort those subjects who carry on at least one $\mathrm{Z}$ allele had a higher risk for accelerate lung function decline, especially in population subgroups characterized by low-grade inflammation. In agreement with our results, Quint and colleagues [18] neither found significant differences in lung function associated with $11478 \mathrm{G} \rightarrow \mathrm{A}$ polymorphism. These findings suggest that rs1303 and rs709932 are not associated with lung function decline in COPD related to tobacco smoking and biomass burning.

Due to the important number of patients with lower levels of AAT without known risk-alleles, such as $\mathrm{S}$ and $\mathrm{Z}$, it is necessary later investigations to evaluate how these variants participate in COPD pathogenesis and to offer a better diagnosis and treatment.

This study is not free of limitations. Maybe the most important is that we were not able to measure AAT levels. Furthermore, this is a retrospective study and can have memory bias (in expositional variables referred by participants); the sample size was reduced when we realized the exacerbations analysis due to the missed data in clinical records; finally, for the rs 1303 , the statistical power is $<80 \%$ probably due its relatively low allele frequency in the studied population, which must be taken into consideration and possibly require later population validation. Among strengths are the sample size, which is large, and we have two comparison groups (COPD related to tobacco smoking and biomass-burning smoke exposure). Moreover, this is the first time that rs709932 and rs1303 are evaluated in COPD related to biomass-burning smoke.

\section{Materials and Methods}

\subsection{Study Population}

Case and Control Groups

One thousand and seven hundred subjects were included in this case-control study. These subjects attended the COPD and smoking cessation support clinics, both are part of the Department of Smoking and COPD Research Department of the Instituto Nacional de Enfermedades Respiratorias Ismael Cosio Villegas (INER), Mexico.

The sample included 297 patients with the diagnosis of COPD related to tobacco smoking (COPD-S) and 178 with COPD related to biomass-burning exposure (COPD-BB). The COPD diagnosis was confirmed using pulmonary function tests considering a ratio of forced expiratory volume in the first second/forced vital capacity $\left(\mathrm{FEV}_{1} / \mathrm{FVC}\right)<70 \%$ after post-bronchodilator use according to the reference values for Mexicans obtained by Perez-Padilla et al. [41]. Individuals $\geq 50$ years, with a tobacco index $\geq 10$ packs/year and a history of never have been exposed to biomass-burning, were classified in the COPD-S group, and those $\geq 50$ years, with an exposure index $\geq 100 \mathrm{~h} /$ year to biomass-burning exposure, never-smokers, were classified into the COPD-BB group. In addition, the patients' groups (COPD-S and COPD-BB) were divided into two subgroups: frequent-exacerbators (FE-S and FE-BB, respectively) ( $\geq 2$ exacerbations per year) and non-exacerbators (NEX-S and NEX-BB, respectively) with 
emphysema or chronic bronchitis ( $<2$ exacerbations per year), according to Spanish COPD Guidelines (GesEPOC) [42]. Exacerbations were diagnosed and classified according to Anthonisen criteria [43]. In addition, GOLD I and II stages were grouped as G1, and III and IV stages as G2. Exacerbations history was obtained from medical records and those patients who did not have information about exacerbations were excluded from this analysis. Consecutive COPD patients were enrolled from the COPD support clinic attending from 2009 to 2015.

The control groups were according to cases exposition risk factors as follows: a group of smokers without COPD (SWOC, $n=674$ ), with no evidence of pulmonary disease and normal spirometry parameters. Finally, a group of biomass-burning exposed subjects (BBES, $n=551$ ) without a background of active or passive smoking and no evidence of pulmonary disease and normal spirometry parameters, was also included.

Cases and controls of biomass-burning exposure are part of the national program for equality between women and men with the "Diagnóstico oportuno de EPOC/Respirar sin humo" campaign in women living in rural areas, mainly in the northern highlands of the state of Oaxaca and suburban [44] areas of the Tlalpan mayoralty of Mexico City. Subjects attending campaigns from 2014 to 2018 were included.

All participants underwent a background questionnaire of inherited pathologies, whereby subjects who reported suffering some type of lung and/or chronic inflammatory disease were excluded, as well subjects with non-Mexican ancestry (with no Mexican-birth parents and grandparents). A brief flowchart of the subjects' selection is shown in Supplementary Figure S5.

In addition, participants were previously invited to participate in the study; they signed an informed consent document and were provided with a privacy statement describing the protection of personal data. Both documents were approved by the Science and Research Bioethics Committee of this institute (approbation protocol codes: B10-12 and B11-19, approved on May 2014 and May 2019, respectively). All experiments were performed in accordance with the relevant guidelines and regulations. The STREGA (STrengthening the REporting of Genetic Association) guidelines were taken into consideration in the design of this genetic association study.

\subsection{DNA Extraction}

The DNA was extracted from peripheral blood cells via venipuncture, using the commercial BDtract Genomic DNA isolation kit (Maxim Biotech, San Francisco, CA, USA). The DNA was then quantified by UV absorption spectrophotometry at the 260-nm wavelength using a NanoDrop system (Thermo Scientific, Wilmington, DE, USA).

\subsection{SNPs' Selection}

SNPs were selected based on bibliographic search, identifying polymorphisms previously associated with other inflammatory and respiratory diseases. Moreover, we considered an allelic frequency (MAF) higher than 5\%. SNPs evaluated were rs709932 and rs1303 (SERPINA1). Table 5 summarizes the principal characteristics of evaluated SNPs.

Table 5. Characteristics of SNPs.

\begin{tabular}{cccccccc}
\hline Gene & SNP & Alleles & PiM Subtypes & $\begin{array}{c}\text { MAF in Mexicans } \\
\text { (LA) }\end{array}$ & $\begin{array}{c}\text { Chromosome } \\
\text { Position }\end{array}$ & Aminoacid Change & Consequence \\
\hline \multirow{2}{*}{ SERPINA1 } & rs709932 & C/T & M2/M4 & 0.06 & chr14:9438286 & R (Arg) 102 H (His) & $\begin{array}{c}\text { Missense } \\
\text { variant }\end{array}$ \\
\cline { 2 - 7 } & rs1303 & T/G & M3 & 0.28 & chr14:94378506 & E (Glu) 376 D (Asp) & $\begin{array}{c}\text { Missense } \\
\text { variant }\end{array}$ \\
\hline
\end{tabular}

\subsection{Genotyping of the SNPS}

The allelic discrimination of SNPs was performed using the commercial TaqMan probes (Applied Biosystems, San Francisco California, USA) at a concentration of 20X. We used the technique of qPCR 
in a 7300 Real-Time PCR System kit (Applied Biosystems, San Francisco, CA, USA), and the analysis was performed by the SDS (sequence detection software) version 1.4 software (Applied Biosystems, San Francisco, CA, USA).

Haploview version 4.2 was used to determine the presence of haplotypes in the SERPINA1 gene associated with COPD susceptibility.

\subsection{Lung Function}

According to ambient risk factors (tobacco smoking or biomass-burning smoke exposure), patients were divided into two groups: patients with the common genotype and subjects heterozygous + homozygous to the minor allele for each SNP (rs1303: TT vs. TG vs. GG and rs709932: CC vs. CT + TT). The Median test was used to compare lung function values.

\subsection{Statistical Analysis}

The differences between groups under study were evaluated by determining and comparing the allele, genotype, and haplotype frequencies. Statistical significance was assessed using the SPSS v20.0 (SPSS Inc., Chicago, IL, USA) and Epi Info 7.1.4.0 (Centers for Disease Control and Prevention, Atlanta, GA, USA) statistical software, considering the $\chi^{2}$ values, as well as Mann-Whitney U test to comparing cases and control groups. The results were considered significant when the $p$-value was $<0.05$; similarly, the odds ratios (OR) with $95 \%$ confidence intervals (CI) were estimated to determine the strength of the association. A logistic regression analysis was carried out to adjust by potential confounding variables using Plink v. 1.07 [45].

\section{Conclusions}

In conclusion, SNPs in SERPINA1 different from PiS and PiZ are not associated with COPD related to tobacco smoking and biomass-burning susceptibility neither with frequent exacerbations. However, a haplotype (CT haplotype, from rs709932 and rs1303, respectively) is associated with reduced risk for COPD related to tobacco smoking.

Supplementary Materials: Supplementary materials can be found at http://www.mdpi.com/1422-0067/21/1/195/s1.

Author Contributions: All the authors have contributed significantly. In this study, M.A.P.-G., G.P.-R., and R.F.-V. have realized analysis, interpretation of data, and preparation and drafting of the manuscript. J.G.-G. and A.G.-C. have performed experimental work. R.H.-Z. has supervised the study as clinical investigators and critically reviewed the study proposal. A.R.-V. and R.F.-V. have contributed to data collection and analysis and reviewed the manuscript critically. All authors have read and agreed to the published version of the manuscript.

Funding: This work is supported by the allocated budget to research (RFV-HLA Laboratory) from the Instituto Nacional de Enfermedades Respiratorias Ismael Cosio Villegas (INER), and also supported by the resource assigned to INER, managed in Legislatures of the Chamber of Deputies, through its Committee on Equality and Gender, for the budgetary allocation for the Care of Using Wood Associated Diseases.

Acknowledgments: The authors wish to thank Instituto Nacional de Enfermedades Respiratorias Ismael Cosio Villegas for the facilities to carry out this research. The authors acknowledge the support received from physicians and technicians from the COPD clinic at INER for confirmation of diagnosis, acquisition of data on lung function, and clinical care of the study participants.

Conflicts of Interest: The authors declare no competing interests. 


\section{Abbreviations}

$\begin{array}{ll}\text { COPD } & \text { Chronic Obstructive Pulmonary Disease } \\ \text { COPD-S } & \text { Chronic Obstructive Pulmonary Disease related to tobacco smoking } \\ \text { COPD-BB } & \text { Chronic Obstructive Pulmonary Disease related to biomass burning smoke } \\ \text { SWOC } & \text { Smokers without COPD } \\ \text { BBES } & \text { Biomass burning exposed subjects } \\ \text { BEI } & \text { Biomass exposure index } \\ \text { GOLD } & \text { Global Initiative for Chronic Obstructive Lung Disease } \\ \text { SNP } & \text { Single Nucleotide Polymorphism } \\ \text { MAF } & \text { Minor allele frequency } \\ \text { SERPINA1 } & \text { Serpin family A member } 1 \\ \text { PiS } & \text { Protease inhibitor S } \\ \text { PiZ } & \text { Protease inhibitor Z } \\ \text { AAT } & \text { Alpha-1 antitrypsin } \\ \text { AATd } & \text { Alpha-1 antitrypsin deficiency } \\ \text { FE } & \text { Frequent exacerbators } \\ \text { NEX } & \text { Non-exacerbators } \\ \text { FEV } & \text { Forced expiratory volume in the first second } \\ \text { FVC } & \text { Forced vital capacity }\end{array}$

\section{References}

1. The Global Initiative for Chronic Obstructive Lung Disease (GOLD). Global Initiative for Chronic Obstructive Lung Disease (2019 Report). 2019, pp. 2-14. Available online: www.goldcopd.org (accessed on 14 September 2019).

2. Mathers, C.D.; Loncar, D. Projections of global mortality and burden of disease from 2002 to 2030. PLoS Med. 2006, 3, e442. [CrossRef] [PubMed]

3. Menezes, A.M.B.; Pérez-Padilla, R.; Jardim, J.B.; Muiño, A.; López, M.V.; Valdivia, G.; De Oca, M.M.; Tálamo, C.; Hallal, P.C.; Victora, C.G. Chronic obstructive pulmonary disease in five Latin American cities (the PLATINO study): A prevalence study. Lancet 2005, 26, 1875-1881. [CrossRef]

4. Lara, B. EPOC y déficit de alfa-1-antitripsina. Arch. Bronconeumol. 2010, 46 (Suppl. 4), 2-8. [CrossRef]

5. Salahuddin, P. Genetic variants of alpha1-antitrypsin. Clin. Genet. 2010, 11, 101-117.

6. Fregonese, L.; Stolk, J.; Frants, R.R.; Veldhuisen, B. Alpha-1 antitrypsin null mutations and severity of emphysema. Respir. Med. 2008, 102, 876-884. Available online: http://www.ncbi.nlm.nih.gov/pubmed/ 18353624 (accessed on 14 September 2019). [CrossRef]

7. Pérez-Rubio, G.; Jiménez-Valverde, L.O.; Ramírez-Venegas, A.; Camarena, Á.; Sansores, R.H.; Flores-Trujillo, F.; Reséndiz-Hernández, J.M.; Falfán-Valencia, R. Prevalence of alpha-1 antitrypsin high-risk variants in Mexican mestizo population and their association with lung function values. Arch. Bronconeumol. 2015, 51, 80-85. Available online: http://www.ncbi.nlm.nih.gov/pubmed/25454901 (accessed on 14 September 2019). [CrossRef]

8. Acquier, M.F.V.; Lorenzón, S.; Sáez, J.O.P.; Sorroche, P.M.S.; Pace, Y.E.; Giugno. Análisis De Las Discordancias Genotípicas y Fenotípicas en Pacientes Con Déficit de Alfa1 Antitripsina en Argentina. Arch. Bronconeumol. 2018, 54, 1-22.

9. Brode, S.K.; Ling, S.C.; Chapman, K.R. Alpha-1 antitrypsin deficiency: A commonly overlooked cause of lung disease. CMAJ 2012, 184, 1365-1371. [CrossRef]

10. Golpe, R.; Martín-Robles, I.; Sanjuán-López, P.; Pérez-de-Llano, L.; González-Juanatey, C.; López-Campos, J.L.; Arellano-Orden, E. Differences in systemic inflammation between cigarette and biomass smoke-induced COPD. Int. J. Chron. Obstruct. Pulmon. Dis. 2017, 12, 2639-2646. Available online: http://www.ncbi.nlm.nih. gov/pubmed/28979110 (accessed on 1 February 2019). [CrossRef] 
11. Reséndiz-Hernández, J.M.; Ambrocio-Ortiz, E.; Pérez-Rubio, G.; Lopez-Flores, L.A.; Abarca-Rojano, E.; Pavón Romero, G.F.; Flores-Trujillo, F.; Hernández-Zenteno, R.D.J.; Camarena, Á.; Perez-Rodriguez, M.E.; et al. TNF promoter polymorphisms are associated with genetic susceptibility in copd secondary to tobacco smoking and biomass burning. Int. J. Chron. Obstruct. Pulmon. Dis. 2018, 13, 627-637. Available online: http://www.ncbi.nlm.nih.gov/pubmed/29497291 (accessed on 10 June 2018). [CrossRef]

12. Arkhipov, V.; Arkhipova, D.; Miravitlles, M.; Lazarev, A.; Stukalina, E. Characteristics of copd patients according to gold classification and clinical phenotypes in the russian federation: The support trial. Int. J. Chron. Obstruct. Pulmon. Dis. 2017, 12, 3255-3262. Available online: http://www.ncbi.nlm.nih.gov/pubmed/ 29138554 (accessed on 29 September 2019). [CrossRef]

13. Han, M.K.; Quibrera, P.M.; Carretta, E.E.; Barr, R.G.; Bleecker, E.R.; Bowler, R.P.; Cooper, C.B.; Comellas, A.; Couper, D.J.; Curtis, J.L.; et al. Frequency of exacerbations in patients with chronic obstructive pulmonary disease: An analysis of the SPIROMICS cohort. Lancet Respir. Med. 2017, 5, 619-626. [CrossRef]

14. Donaldson, G.C.; Müllerova, H.; Locantore, N.; Hurst, J.R.; Calverley, P.M.; Vestbo, J.; Anzueto, A.; Wedzicha, J.A. Factors associated with change in exacerbation frequency in COPD. Available online: https://respiratory-research.biomedcentral.com/track/pdf/10.1186/1465-9921-14-79?site=respiratoryresearch.biomedcentral.com (accessed on 16 January 2018).

15. Brusse-Keizer, M.; van der Palen, J.; van der Valk, P.; Hendrix, R.; Kerstjens, H. Clinical predictors of exacerbation frequency in chronic obstructive pulmonary disease. Clin. Respir. J. 2011, 5, 227-234. Available online: http://www.ncbi.nlm.nih.gov/pubmed/21106031 (accessed on 29 September 2019). [CrossRef] [PubMed]

16. Hill, A.T.; Campbell, E.J.; Bayley, D.L.; Hill, S.L.; Stockley, R.A. Evidence for excessive bronchial inflammation during an acute exacerbation of chronic obstructive pulmonary disease in patients with alpha(1)-antitrypsin deficiency (PiZ). Am. J. Respir. Crit. Care Med. 1999, 160, 1968-1975. Available online: http://www.ncbi.nlm. nih.gov/pubmed/10588615 (accessed on 6 October 2019). [CrossRef] [PubMed]

17. Fujimoto, K.; Ikeda, S.; Arai, T.; Tanaka, N.; Kumasaka, T.; Ishii, T.; Kida, K.; Muramatsu, M.; Sawabe, M. Polymorphism of serpine2 gene is associated with pulmonary emphysema in consecutive autopsy cases. BMC Med. Genet. 2010, 11, 159. Available online: http://www.ncbi.nlm.nih.gov/pubmed/21067581 (accessed on 6 October 2019). [CrossRef] [PubMed]

18. Quint, J.K.; Donaldson, G.C.; Kumari, M.; Talmud, P.J.; Hurst, J.R. SERPINA1 11478G-A variant, serum $\alpha 1$-antitrypsin, exacerbation frequency and FEV1 decline in COPD. Thorax 2011, 66, 418-424. [CrossRef]

19. Deng, X.; Yuan, C.-H.; Chang, D. Interactions between single nucleotide polymorphism of serpina1 gene and smoking in association with copd: a case-control study. Int. J. Chron. Obstruct. Pulmon. Dis. 2017, 12, 259-265. Available online: http://www.ncbi.nlm.nih.gov/pubmed/28138235 (accessed on 6 October 2019). [CrossRef]

20. Falfan-Valencia, R.; Pérez-Rubio, G.; Ambrocio-Ortiz, E.; Juárez-Martín, A.; Jiménez-Valverde, L.; Zoreque-Cabrera, S.; Galicia-Negrete, G.; Guevara, R.; Castillejos-López, M.; Salinas-Lara, C.; et al. Heterozygous genotype rs17580 AT (PiS) in SERPINA1 is associated to COPD secondary to biomass and tobacco smoke. Eur. Respir. Soc. (ERS) 2017, 50, PA962.

21. Takabatake, N.; Shibata, Y.; Abe, S.; Wada, T.; Machiya, J.; Igarashi, A.; Tokairin, Y.; Ji, G.; Sato, H.; Sata, M.; et al. A single nucleotide polymorphism in the CCL1 gene predicts acute exacerbations in chronic obstructive pulmonary disease. Am. J. Respir. Crit. Care Med. 2006, 174, 875-885. Available online: http://www.ncbi.nlm.nih.gov/pubmed/16864713 (accessed on 30 November 2017). [CrossRef]

22. Foreman, M.G.; DeMeo, D.L.; Hersh, C.P.; Carey, V.J.; Fan, V.S.; Reilly, J.J.; Shapiro, S.D.; Silverman, E.K. Polymorphic variation in surfactant protein $\mathrm{b}$ is associated with COPD exacerbations. Eur. Respir. J. 2008, 32, 938-944. Available online: http://www.ncbi.nlm.nih.gov/pubmed/18550614 (accessed on 8 October 2019). [CrossRef]

23. Dicker, A.J.; Crichton, M.L.; Cassidy, A.J.; Brady, G.; Hapca, A.; Tavendale, R.; Einarsson, G.G.; Furrie, E.; Elborn, J.S.; Schembri, S.; et al. Genetic mannose binding lectin deficiency is associated with airway microbiota diversity and reduced exacerbation frequency in COPD. Thorax 2018, 73, 510-518. Available online: http://www.ncbi.nlm.nih.gov/pubmed/29101284 (accessed on 9 October 2019). [CrossRef] [PubMed] 
24. Platé, M.; Lawson, P.J.; Hill, M.R.; Quint, J.K.; Kumari, M.; Laurent, G.J.; Wedzicha, J.A.; Chambers, R.C.; Hurst, J.R. Impact of a functional polymorphism in the PAR-1 gene promoter in COPD and COPD exacerbations. Am. J. Physiol. Lung. Cell Mol. Physiol. 2014, 307, L311-L3116. Available online: http://www.ncbi.nlm.nih.gov/pubmed/24973402 (accessed on 30 November 2017). [CrossRef] [PubMed]

25. Ingebrigtsen, T.S.; Marott, J.L.; Rode, L.; Vestbo, J.; Lange, P.; Nordestgaard, B.G. Fibrinogen and $\alpha 1$-antitrypsin in COPD exacerbations. Thorax 2015, 70, 1014-1021. [CrossRef] [PubMed]

26. Chappell, S.; Daly, L.; Morgan, K.; Guetta Baranes, T.; Roca, J.; Rabinovich, R.; Millar, A.; Donnelly, S.C.; Keatings, V.; MacNee, W.; et al. Cryptic haplotypes of SERPINA1 confer susceptibility to chronic obstructive pulmonary disease. Hum. Mutat. 2006, 27, 103-109. Available online: http://www.ncbi.nlm.nih.gov/pubmed/ 16278826 (accessed on 10 October 2019). [CrossRef]

27. Echazarreta, A.L.; Márquez, S.E.; Curró, M.F.; Macuso, M.O.; Lardizábal, A.; Correa, Y.; Outón, V.; Sánchez, Y.M. Deficiencia grave de afa-1 antitripsina: Utilidad del screening en una cohorte de 1.040 pacientes con patología respiratoria crónica. Arch. Bronconeumol. 2018, 54, 13-14.

28. Bassani, Y. Programa de cribado para el déficit De alfa 1-antitripsina en el servicio de neumonología del Hospital Tránsito Cáceres de Allende. Rev. Am. Med. Respir. 2017, 17, 38-45.

29. Sorroche, P.B.; Fernández Acquier, M.; López Jove, O.; Giugno, E.; Pace, S.; Livellara, B.; Legal, S.; Oyhamburu, J.; Saez, M.S. Déficit de alfa 1 antitripsina en pacientes con EPOC: Estudio de corte transversal. Arch. Bronconeumol. 2015, 51, 539-543. [CrossRef]

30. Ferrarotti, I.; Thun, G.A.; Zorzetto, M.; Ottaviani, S.; Imboden, M.; Schindler, C.; Von Eckardstein, A.; Rohrer, L.; Rochat, T.; Russi, E.W.; et al. Serum levels and genotype distribution of $\alpha 1$-antitrypsin in the general population. Thorax 2012, 67, 669-674. Available online: http://www.ncbi.nlm.nih.gov/pubmed/22426792 (accessed on 6 October 2019). [CrossRef]

31. DeLuca, D.S.; Poluzioroviene, E.; Taminskiene, V.; Wrenger, S.; Utkus, A.; Valiulis, A.; Alasevičius, T.; Henderson, J.; Bush, A.; Welte, T.; et al. SERPINA1 gene polymorphisms in a population-based ALSPAC cohort. Pediatr. Pulmonol. 2019, 54, 1474-1478. [CrossRef]

32. Caglar, F.N.T.; Isiksacan, N.; Biyik, I.; Tureli, H.O.; Katkat, F.; Karabulut, D.; Oztas, D.M.; Ugurlucan, M. Is there any association between rs1303 ( $\mathrm{Pi}^{*} \mathrm{M} 3$ ) variant of alpha-1 antitrypsin gene and atrial septal aneurysm development? J. Card. Surg. 2019, 34, 1215-1219. Available online: http://www.ncbi.nlm.nih.gov/pubmed/ 31523846 (accessed on 12 October 2019). [CrossRef]

33. Denden, S.; Haj Khelil, A.; Perrin, P.; Daimi, H.; Leban, N.; Ouaja, A.; Mahdouani, K.; Hlioui, L.; Lefranc, G.; Ben Chibani, J. Alpha 1 antitrypsin polymorphism in the Tunisian population with special reference to pulmonary disease. Pathol. Biol. (Paris) 2008, 56, 106-110. Available online: http://www.ncbi.nlm.nih.gov/ pubmed/18031952 (accessed on 12 October 2019). [CrossRef] [PubMed]

34. Gupta, J.; Bhadoria, D.P.; Lal, M.K.; Kukreti, R.; Chattopadhaya, D.; Gupta, V.K.; Dabur, R.; Yadav, V.; Chhillar, A.; Sharma, G. Association of the PIM3 allele of the alpha-1-antitrypsin gene with chronic obstructive pulmonary disease. Clin. Biochem. 2005, 38, 489-491. Available online: http://www.ncbi.nlm.nih.gov/ pubmed/15820782 (accessed on 6 October 2019). [CrossRef] [PubMed]

35. Ozretić, P.; da Silva Filho, M.I.; Catalano, C.; Sokolović, I.; Vukić-Dugac, A.; Šutić, M.; Kurtović, M.; Bubanović, G.; Grle, P.; Cincar, S.; et al. Association of NLRP1 Coding Polymorphism with Lung Function and Serum IL-1 $\beta$ Concentration in Patients Diagnosed with Chronic Obstructive Pulmonary Disease (COPD). Genes 2019, 10, 783.

36. Bchir, S.; ben Nasr, H.; Garrouch, A.; ben Anes, A.; Abbassi, A.; Tabka, Z.; Chahed, K. MMP-3 (-1171 5A/6A; Lys45Glu) variants affect serum levels of matrix metalloproteinase (MMP)-3 and correlate with severity of COPD: A study of MMP-3, MMP-7 and MMP-12 in a Tunisian population. J. Gene. Med. 2018, 20. [CrossRef]

37. Córdoba-Lanús, E.; Baz-Dávila, R.; Espinoza-Jiménez, A.; Rodríguez-Pérez, M.C.; Varo, N.; De-Torres, J.P.; González-Almeida, D.; Aguirre-Jaime, A.; Casanova, C. IL-8 gene variants are associated with lung function decline and multidimensional BODE index in COPD patients but not with disease susceptibility: A validation study. COPD J. Chronic Obstr. Pulm. Dis. 2015, 12, 55-61. [CrossRef]

38. van Diemen, C.C.; Postma, D.S.; Siedlinski, M.; Blokstra, A.; Smit, H.A.; Boezen, H.M. Genetic variation in TIMP1 but not MMPs predict excess FEV 1decline in two general population-based cohorts. Respir. Res. 2011, 12, 57. [CrossRef] 
39. Kaparianos, A.; Argyropoulou, E.; Efremidis, G.; Flordellis, C.; Spiropoulos, K. Decline in FEV1 related to genetic polymorphisms (+138insA/delA and Lys198Asn) of the endothelin-1 gene in COPD. A pilot study-PubMed-NCBI. Eur. Rev. Med. Pharmacol. Sci. 2010, 14, 705-719. Available online: https: //www.ncbi.nlm.nih.gov/pubmed/20707291 (accessed on 22 October 2019).

40. Thun, G.A.; Ferrarotti, I.; Imboden, M.; Rochat, T.; Gerbase, M.; Kronenberg, F.; Bridevaux, P.-O.; Zemp, E.; Zorzetto, M.; Ottaviani, S.; et al. SERPINA1 PiZ and PiS heterozygotes and lung function decline in the SAPALDIA cohort. PLoS ONE 2012, 7, e42728. [CrossRef]

41. Pérez-Padilla, R.; Valdivia, G.; Muiño, A.; López, M.V.; Márquez, M.N.; de Oca, M.M.; Tálamo, C.; Lisboa, C.; Pertuzé, J.; Jardim, F.R.B.; et al. Spirometric Reference Values in 5 Large Latin American Cities for Subjects Aged 40 Years or Over. Arch. Bronconeumol. 2006, 42, 317-325. Available online: http://www.platino-alat.org/docs/paper_perez-padilla_2006_ENG.pdf (accessed on 30 November 2017). [CrossRef]

42. Miravitlles, M.; Soler-Cataluña, J.J.; Calle, M.; Molina, J.; Almagro, P.; Quintano, J.A.; Riesco, J.A.; Trigueros, J.A.; Piñera, P.; Simón, A.; et al. Spanish COPD Guidelines (GesEPOC): Pharmacological treatment of stable COPD. Spanish Society of Pulmonology and Thoracic Surgery. Arch. Bronconeumol. 2012, 48, 247-257. Available online: http://www.archbronconeumol.org/es/guia-espanola-epoc-gesepoctratamiento/articulo/S0300289612001159/ (accessed on 14 September 2019). [CrossRef]

43. Anthonisen, N.R.; Manfreda, J.; Warren, C.P.; Hershfield, E.S.; Harding, G.K.; Nelson, N.A. Antibiotic therapy in exacerbations of chronic obstructive pulmonary disease. Ann. Int. Med. 1987, 106, 196-204. Available online: http://www.ncbi.nlm.nih.gov/pubmed/3492164 (accessed on 19 June 2017). [CrossRef] [PubMed]

44. Ramírez-Venegas, A.; Velázquez-Uncal, M.; Pérez-Hernández, R.; Guzmán-Bouilloud, N.E.; Falfán-Valencia, R.; Mayar-Maya, M.E.; Aranda-Chavez, A.; Sansores, R.H. Prevalence of COPD and respiratory symptoms associated with biomass smoke exposure in a suburban area. Int. J. COPD 2018, 13, 1727-1734. [CrossRef] [PubMed]

45. Purcell, S.; Neale, B.; Todd-Brown, K.; Thomas, L.; Ferreira, M.A.R.; Bender, D.; Maller, J.; Sklar, P.; De Bakker, P.I.W.; Daly, M.J.; et al. PLINK: A Tool Set for Whole-Genome Association and Population-Based Linkage Analyses. Am. J. Hum. Genet. 2007, 81, 559-575. [CrossRef] [PubMed]

(C) 2019 by the authors. Licensee MDPI, Basel, Switzerland. This article is an open access article distributed under the terms and conditions of the Creative Commons Attribution (CC BY) license (http://creativecommons.org/licenses/by/4.0/). 